\title{
Role of Telecommunication Sector Towards Government Revenue Generation in Nepal (A Case Study of Nepal Telecom Limited)
}

\author{
Pravesh Ghimire \\ Nepal Commerce Campus, Tribhuvan University, Kathmandu, Nepal
}

Email address:

pravesh_ghimire@hotmail.com

\section{To cite this article:}

Pravesh Ghimire. Role of Telecommunication Sector Towards Government Revenue Generation in Nepal (A Case Study of Nepal Telecom Limited). International Journal of Business and Economics Research. Vol. 8, No. 5, 2019, pp. 245-256. doi: 10.11648/j.ijber.20190805.11

Received: June 14, 2019; Accepted: July 18, 2019; Published: July 31, 2019

\begin{abstract}
Worldwide, telecommunication sector has been playing a significant role towards public revenue generation. In Nepal, also it is one of the important sectors, which contributes on government revenue generation through paying direct and indirect taxes. This study aims to highlight the contribution of Nepal Telecom: a government incorporated telecommunication organization of Nepal towards government revenue generation. The study has also recognized areas relating to existing scenario of tax payment system of Nepal Telecom with exploring some possible solutions for improvement. The research design used in this study has been descriptive and analytical. Both qualitative and quantitative methods have been followed to make the research more empirical. The information and data required for this study have been taken from primary and secondary sources. The data from F/Y 2007/08 to F/Y 2016/17 have been taken for analysis of tax revenue. Data processing and tabulations have been done by using Microsoft Excel and SPSS. Descriptive as well as inferential statistical tools have been used for analyzing data and draw conclusions. Advanced statistical tools like co-relation, multiple regression and time series analysis have been done and also verified the results by using test statistics (t-tests and f-tests). The study concluded that Nepal Telecom has been playing significant role towards government revenue generation through its income tax, VAT and TDS contributions.
\end{abstract}

Keywords: Tax, Nepal Telecom, Telecommunication, Government Revenue, Co-relation, Multiple Regression, Time Series Analysis

\section{Introduction}

A government needs different sources of revenues to carry out various functions for the betterment of its citizens. The fundamental objective of taxation is to finance government expenditure. The government requires carrying out various development and welfare activities in the country which it does by imposing taxes. The government not only raises public revenue through taxation, but also, imposes restrictions on the use of certain goods. The government can impose excise duty on tobacco, liquor etc. to restrict the consumption of harmful goods. Similarly, taxes can correct for externalities and other forms of market failure such as monopoly. In this way, the government regulates the economy in accordance with the needs of the country. Tax is imposed on persons according to their income level. High earners are imposed high tax through progressive tax system. It prevents wealth from being concentrated in a few hands of the rich and hence narrows down the gap between the rich and the poor. [1]

A direct tax is a mandatory payment by a person to whom it is legally imposed. It is collected directly by the government from the person who bears the tax burden. Taxpayers need to file tax returns directly to the government such that, direct tax cannot be shifted. The impact or the money burden and the incidence are on the one and the same person. It is the tax on income and property. Examples of direct tax include income tax, property tax, vehicle tax, interest tax, expenditure tax, death tax, gift tax, etc. Direct Tax is equitable as it is imposed on person as per the size of property or income. Time, procedure and amount of tax to be paid is known with certainty. The cost of collecting direct 
taxes is low as they are mostly collected "at the source". An indirect tax is the payment imposed on one person but partially or wholly paid by another as the burden of tax is shifted to other. An indirect tax is a form of tax imposed on one person but partly or wholly paid by another. It is collected by mediators who transfer the taxes to the government and also perform functions associated with filing tax returns. Hence, indirect tax can be shifted. In indirect tax, the impact and incidence of tax are on different persons. In other words, the person paying and bearing the tax is different. It is the tax on consumption or expenditures. Examples include VAT, excise duty, import \& export duty. It is more convenient as the taxpayer does not have to pay a lump sum amount for tax. It is paid in small amounts and only when making purchases. There is mass participation as each and every person getting goods or services has to pay tax. Indirect tax is also the means of reaching the poor as they are generally exempted from paying direct taxes. There is less chance of tax evasion as the taxpayers pay the tax collected from customers. The collection of tax takes automatically when goods are bought and sold. [2]

Tax collected by the government is spent for carrying out various welfare use activities. It helps in redistributing wealth in the country. It also serves as an instrument for promoting economic growth, stability and efficiency. The government controls or expands economic activities of a country by providing various concessions, rebates and other facilities. Low rate of taxation during a business depression will accelerate more income to the people and help in raising demand and thus revive business activity. On the contrary, high rates may be useful to check inflationary pressure on prices. The government provides tax exemptions or concessions for industries established or activities carried out in backward areas. This will help increase economic activities in those areas and ultimately regional disparity can be reduced. [3]

In Nepal, operating any form of telecommunication service dates back to 1916 A.D. In order to modernize and expand telecommunications services telecommunications development board was established in 1969. After the enactment of Communications Corporation Act 1971, it was formally established as a fully owned government corporation of Nepal called Nepal Telecommunications Corporation in 1975. After serving the nation for 29 years, Nepal Telecommunication Corporation was transformed into Nepal Doorsanchar Company Limited (NDCL) in $13^{\text {th }}$ April 2004. However, the company is known to the general public by the brand name "Nepal Telecom" as its registered trademark. The mission of the Nepal Telecom is to develop Nepal Telecom as a progressive, customer spirited and consumer responsive entity. It is committed to provide nation-wide reliable telecommunication service to serve as an impetus to the social, political and economic development of the country. The vision of Nepal Telecom is to remain a dominant player in telecommunication sector in the country while also extending reliable and cost effective services to all. The goal of Nepal Telecom is to provide cost effective telecommunication services to every corners of the country. Since its inception, Nepal Telecom has always put its endeavors in providing its valued customers a quality service. In order to achieve this goal, technologies best meeting the interest of its customers have always been selected. The nationwide reach of the organization, from urban areas to the economically non- viable most remote locations, is the result of all these efforts that makes this organization different from others. Converting Nepal Telecom from a government owned corporation to a business oriented, customer focused company, Nepal Telecom invites all the shareholders in the sacred work of nation building. The services provided to individual customers by Nepal Telecom are Public Switched Telephone Network (PSTN) land line service, Global System for Mobile communications (GSM) postpaid, GSM prepaid, Nepal Telecom (NT) data packages, Volume based Asymmetric Digital Subscriber Line (ADSL) service, Fiber to the Home (FTTH), Code Division Multiple Access (CDMA) sky phone, CDMA Evolution Data Optimized (EVDO) service and Easy phone service. Whereas, the services provided to corporate customers by Nepal Telecom are landline services, GSM services, toll free services, notice board services, Dedicated internet \& intranet leased services, ADSL services, CUG - Caller User Group, Worldwide Interoperability for Microwave Access (WiMAX) wireless broadband and Value Added Service (VAS). Nepal Telecom pays various types of taxes and fees to the government of Nepal which is a significant portion of its revenue. Among them advance income tax, valued added tax, telecommunication fees, ownership fees, custom duty, royalty and rural telecommunication development fund, dividend, property and vehicle tax, value receipt are the major sources of tax from Nepal Telecom. [4]

The main objective of this paper is to determine the importance of telecommunication sector, in revenue generation for the government of Nepal. Accordingly, the specific objectives are to highlight the contribution of Nepal Telecom Limited towards government revenue generation through direct and indirect taxes. Further, the study also recognizes problems relating to existing scenario of tax payment system of Nepal Telecom and explore some possible solutions for improvement. The paper promotes emergence of telecommunication sector such that it can have a distinct as well as a remarkable role towards generation of government revenue in developing country like Nepal.

\section{Review of Literature}

Roller et. al. (1996) published a paper entitled "Telecommunications Infrastructure and Economic Development: A Simultaneous Approach". This paper investigates effect of telecommunications investment on economic growth. Information have been collected from twenty- one OECD countries over a period of twenty years. The study concludes that increased investment in telecommunications infrastructure creates higher growth effects in OECD countries than in less-developed non-OECD 
countries. This study suggests for a specific role of government in providing an efficient telecommunication infrastructure to foster economic growth of a country. [5]

Nepal Rastra Bank (2002) published an article entitled, "Trend in Nepal's import duties: implications with future trade liberalization". The study has analyzed the responsiveness of Nepal's import duties with government revenue over the period of $1980 / 1981$ to $2001 / 2002$ by using simple regression analysis and has made projection for the year 2006/07 back. The study has also assessed the impact of trade liberalization on revenue source through elasticity and buoyancy analysis of import duties. It has shown low elasticity and buoyancy of import duties, with government revenue. [6]

Telecommunication Development Bureau (2013) published a report named "Taxing telecommunication/ ICT services: an overview". This paper contains a general, introductory discussion on the effects of imposing special taxes on telecommunication equipment and services in addition to the general taxes, such as VAT, which apply to most or all goods and services. This study shows that, telecommunication taxes will have distributional consequences, but when services are fully diffused, they are difficult to establish. This is because, voice calls in particular are normally paid for the caller but enjoyed by the receiver as well. In the case of telecommunication taxes levied on large national or international operators, collection costs are likely to be low compared with many other taxes. The incidence of tax on equipment may fall on consumers, but the incidence of service taxes may be shared with operators. Moreover, there does not appear to be a conventional reason for generally favoring or disfavoring telecommunication taxes on grounds of excess burden, or because the services are luxury goods or because they have adverse social consequences. The study suggests a tax which slows down the diffusion of telecommunications services: both voice services and broadband and defers the arrival of these benefits. [7]

Nepali Telecom (2016) published a web article named "Nepal Telecom honored for highest value added tax payer". This article had highlighted the contribution of Nepal Telecom on government revenue through Value Added Tax (VAT) for the F/Y 2015/16. The article further mentions that Nepal Telecom is continuously submitting its financial details on time since last 19 years. Due to this, Finance Minister of the government of Nepal had honored the NTC for its role in adding a big sum of money from tax to the national wealth by organizing an event 'the $5^{\text {th }}$ National Tax Day' and providing a certificate of appreciation to the NTC. [8]

Luan (2016) published a paper entitled "A Comparative Study on Replacing Business Tax with Value-Added Tax of Domestic and Foreign Telecommunication Industry". This paper shows the development of value added tax in terms of implementation, levy, change in rates and timely amendments at most of the countries. It further demonstrates that the means of collection and management of value added tax are becoming more advanced due to computer management system of vat returns. Countries all over the world have strengthened the inspection methods of value added through audit methods based on computer done by efficient personnel such that the purview of value added tax can be thoroughly implemented. Moreover, the writer mentions non-deduction of input VAT as a business tax by telecommunication sector in China has caused loss of revenue to the country. In addition, the writer emphasizes the system of the specific practices of collection of VAT in European Union countries mainly by cross border telecommunication industries. The writer concludes the paper by showing, the changes in tax burden obtained by replacing business tax with value added tax in China. [9]

Din et. al. (2016) published a paper entitled "Public Policy, Innovation and Economic Growth: An Economic and Technological Perspective on Pakistan's Telecom Industry". This paper shows the role of public policy on economic growth which depends on the level of investment, the quantity and quality of human capital and improvements in technology. Moreover, the paper shows the various types of telecommunication technologies and innovation in Pakistan which focus on public policy to enhance entrepreneurship, technology and innovation. Impact of liberal investment regime and market competition on modernization after the reregulation has also been shown for telecommunication sector. Regarding tax issues in telecommunication sector, the writers highlight, levy of withholding tax on telecom services by government is substantially higher than that charged on other segments of the economy, such that, now, telecom industries are advocating reduction in telecommunication tax rates. [10]

Erns \& Young (2017) published an article named "US tax reform and the telecommunications industry". This article demonstrates existing provisions of corporate and individual tax rates and highlights a reform policies based on 'The Camp Plan' and 'The Trump Tax Plan' which is a blueprint proposal developed to reduce ambitious tax rates. This study suggests telecommunications companies and professionals to identify and consider those tax reform proposals that may have impact on their businesses. [11]

Matheson et. al. (2017) published a paper named "Taxing Telecommunications in Developing Countries". The paper is based on the study of telecommunication sector of 110 developing countries. This paper shows that government have conflicting objectives regarding tax treatment of the cellular telecommunications industry in developing countries. On the one hand, government want development of telecom sector as they contribute to productivity and growth of economy, whereas, on the other hand, they regard telecom sector was good source of revenue and impose high rates of taxes. The study finds, Telecom sector has huge contribution to revenue of a government through general and sectorspecific taxes like: CIT surcharge, VAT surcharge, excises and custom duties all over the world. In addition, findings related to variables like spectrum license fees, rent taxes, corporate income tax, excise on domestic and international calls, excise on network access, value added tax, input taxes and user fees and tax incentives of all countries are 
presented. The writers conclude the paper by suggesting, a balanced tax regime sharing fiscal and economic risks between investors and the government, such that, different tax instruments should be better structured to curb the current proliferation of telecom taxes and fees. [12]

Forogh et. al. (2017) published a paper named "Service Quality Factors Influencing Customer Satisfaction in Afghanistan's Mobile Telecommunication Industry". The relationship between service quality of telecom industry and customer buying behavior has been taken as a research framework which mainly depend on reliability, network coverage and tax level taken from respondents in Kabul. This study shows that the quality of the services of telecom companies could be enhanced through customer feedbacks, responses to customer complaints, improved network coverage and adaptation of tax prices by personnel training, more investment in up-to-date equipment for further coverage and offering discounts with reasonable rates of taxes to normal subscribers. Further, the paper focusses on customer satisfaction as an important business indicator in telecom industry. [13]

Svetalekth (2018) published a paper entitled "Should Excise Tax be collected on Mobile Services? Experience in Thailand". This paper shows the ambit of excise tax in terms of its rates and its contribution to government revenue at telecommunication industry on Thailand and some other countries. In Thailand since 2007, excise tax was exempted from levy in telecommunication industry which has caused significant reduction in government revenue over time. Further, the paper also demonstrates the existing structure of taxation on telecommunication business and the scope of service tax on mobile phones. The writer affirms collection of service tax from mobile as it contributes to government revenue, reduces extravagant use of mobile phones by teenagers. The writer concludes the paper by recommending levy of excise duty once again in Thailand such that tax revenue collection can be increased and proper use of mobile services by teenagers and youths can be promoted. [14]

Mehta et. al. (2018) published a paper entitled "Tax Payer's Perception towards Goods and Service Tax in India". This paper shows that GST was introduced in India to reduce tax burden of the consumers by reducing cascading effect of taxes through single tax system as well as to introduce more efficient, transparent and simpler tax system. The paper on one hand, demonstrates impact of GST on FMCG Sector, service sector, telecommunications sector and automobiles sector, which showed that all these sectors as such are positively affected by implementation of GST. On the other hand, this paper also highlights on the perception of tax payers towards GST through qualitative data analysis of respondents. It was observed that overall taxpayers were not comfortable with immediate implementation of GST as they felt GST effected their consumption behavior and as a result the taxpayers started consuming goods with prudence consideration. The writers summarize the paper by stating that taxpayers remained unclear with GST enactments and felt that a good tax reform is beneficial in long run rather than immediate implementation which has increased legal compliances, tax burden and prices of goods and services. [15]

\section{Research Methodology}

The research design used in this study has been descriptive, analytical and to some extent explorative. Both qualitative and quantitative methods have been followed to make the research more empirical. The information and data required for this study have been taken from primary and secondary sources. The secondary data has been used to access the contribution of Nepal Telecom Limited towards government revenue generation, collected from Economic Survey of the Government of Nepal [16] and Annual Reports of the Nepal Telecom [17] as provided by the organization. The data from F/Y 2007/08 to F/Y 2016/17 have been taken for analysis of tax revenue. The primary information has been collected through written opinions of key informants from the Accounts Department of Nepal Telecom from the Central Office at Bhadrakali in Kathmandu, in order to know the problems relating to existing tax payment system of Nepal Telecom and explore possible solutions for improvement.

\subsection{Variable Specification}

Total tax contribution of Nepal Telecom includes property tax, vehicle tax, income tax, VAT, TDS and customs duty. Similarly, non-tax contribution of Nepal Telecom includes telecommunication service fees, ownership fees, royalty and value receipt. As the name denotes property tax and vehicle tax refer to property and vehicle taxes paid by Nepal Telecom to Government. Income tax contributed by Nepal Telecom denotes Corporate Income Tax that it pays annuals as a direct tax. VAT contributed by Nepal Telecom denotes net contribution from VAT payable and VAT receivable which is an indirect tax paid to Government. TDS in the study is mainly one which is deducted by banks on interest income of Nepal Telecom. Custom duty is the total duty paid by Nepal Telecom to Department of Customs, under Government of Nepal.

\subsection{Data Presentation and Analysis}

Data processing and presentations were done by using Microsoft Excel and SPSS. Descriptive as well as inferential statistical tools have been used for analyzing data and draw conclusions. Advanced statistical tools like co-relation, multiple regression and time series analysis have been done and also verified the results by using test statistics ( $\mathrm{t}$-tests and f-tests).

\subsection{Model Specification}

\subsubsection{Co-relation}

Co-relation coefficient between government revenue (X) and total tax contribution (Y) has been calculated for Nepal Telecom data from F/Y 2007/08 to F/Y 2016/17. The data for 


\subsubsection{Multiple Regressions}

Although, Nepal Telecom contributes to government revenue through property and vehicle tax, income tax, VAT, TDS and custom duty, however, for the purpose of regression; only income tax, VAT and TDS contributions have been taken from F/Y 2007/08 to F/Y 2016/17 as these components have higher contribution to government revenue in Nepal. Property tax, vehicle tax and custom duty have not been taken because, they have comparatively small contribution to government revenue in comparison to other tax components. Thus, multiple regression has been done to show the relation of government revenue $(\mathrm{Y})$ to income tax $\left(\mathrm{X}_{1}\right)$, VAT $\left(\mathrm{X}_{2}\right)$ and TDS $\left(\mathrm{X}_{3}\right)$. Symbolically,

$$
\mathrm{Y}=\mathrm{a}+\mathrm{b}_{1} \mathrm{X}_{1}+\mathrm{b}_{2} \mathrm{X}_{2}+\mathrm{b}_{3} \mathrm{X}_{3}
$$

Where, $\mathrm{Y}=$ Government revenue, $\mathrm{a}=\mathrm{Y}$ intercept, $\mathrm{b}=$ Slope coefficient, $\mathrm{X}_{1}=$ Income tax contribution, $\mathrm{X}_{2}=\mathrm{VAT}$ and $\mathrm{X}_{3}=$ TDS contributions by Nepal Telecom to government of Nepal.

\subsubsection{Time Series Analysis}

Using the time series data, the straight line trend has been measured to observe change in tax contribution of Nepal Telecom with time by using the equation of straight line trend as:

$$
\mathrm{Y}=\mathrm{a}+\mathrm{bX}
$$

Where, $\mathrm{Y}=$ Total Tax contribution of Nepal Telecom and $\mathrm{X}=$ Time

\subsection{Hypothesis TESTING}

T-test has been used to test each partial regression coefficients for the multiple regression equation. F-test has been calculated for measuring overall significance of the model. [18]

\section{Presentation and Analysis of Data}

\subsection{Contribution of Nepal Telecom to Government Revenue Generation from Various Sources}

The table below shows the overall figures or values of advance income tax, valued added tax, telecommunication fees, ownership fees, custom duty, royalty and rural telecommunication development fund, dividend, property and vehicle tax, value receipt of Nepal Telecom for last ten years (F/Y 2007/08 to 2016/17).

\begin{tabular}{|c|c|c|c|c|c|c|c|c|c|}
\hline & & & & & & & & & (Rs in million) \\
\hline $\mathbf{F} / \mathbf{Y}$ & $\begin{array}{l}\text { Advance } \\
\text { income tax }\end{array}$ & $\begin{array}{l}\text { Value } \\
\text { added tax }\end{array}$ & $\begin{array}{l}\text { Telecommunication } \\
\text { service fees }\end{array}$ & $\begin{array}{l}\text { Ownership } \\
\text { fees }\end{array}$ & $\begin{array}{l}\text { Custom } \\
\text { duty }\end{array}$ & $\begin{array}{l}\text { Royalty and rural } \\
\text { telecommunication } \\
\text { development fund }\end{array}$ & Dividend & $\begin{array}{l}\text { Property } \\
\text { and vehicle } \\
\text { tax }\end{array}$ & Value receipt \\
\hline $2007 / 08$ & $2,838.26$ & $1,441.03$ & $1,239.83$ & 177.86 & 246.09 & $1,003.35$ & $1,499.50$ & 28.08 & $1,201.98$ \\
\hline $2008 / 09$ & $3,648.71$ & $1,768.33$ & $1,561.83$ & 296.88 & 214.89 & $1,007.30$ & $3,431.01$ & 33.59 & 284.75 \\
\hline $2009 / 10$ & $4,231.40$ & $2,736.60$ & $2,059.44$ & 456.56 & 260.48 & $1,228.95$ & $4,803.45$ & 27.62 & - \\
\hline $2010 / 11$ & $4,477.41$ & $2,127.50$ & $1,973.55$ & 431.88 & 228.96 & $1,503.50$ & $5,489.60$ & 45.27 & - \\
\hline $2011 / 12$ & $5,270.10$ & $2,452.62$ & $2,064.91$ & 486.98 & 122.22 & $1,584.57$ & $6,175.80$ & 44.95 & - \\
\hline $2012 / 13$ & $3,630.93$ & $3,560.09$ & $2,086.61$ & 434.30 & 527.92 & $1,968.45$ & $6,587.52$ & 42.33 & - \\
\hline $2013 / 14$ & $7,075.94$ & $3,865.70$ & $2,350.90$ & 470.61 & 190.22 & $2,046.51$ & $6,313.04$ & 42.45 & - \\
\hline $2014 / 15$ & $4,849.35$ & $4,152.24$ & $2,365.26$ & 636.06 & 123.48 & $2,133.55$ & $6,450.28$ & 47.47 & - \\
\hline $2015 / 16$ & $5,734.59$ & $4,352.16$ & $2,908.46$ & 540.26 & 308.37 & $2,355.58$ & $6,862.00$ & 45.17 & - \\
\hline $2016 / 17$ & $6,148.28$ & $4,752.77$ & $3,203.06$ & 598.21 & 368.32 & $2,442.25$ & $6,999.24$ & 34.80 & - \\
\hline Total & $47,904.98$ & $31,209.03$ & $21,813.84$ & $4,529.59$ & $2,590.96$ & $17,274.00$ & $54,611.43$ & 391.72 & $1,486.73$ \\
\hline Average & $4,790.50$ & $3,120.90$ & $2,181.38$ & 452.96 & 259.10 & $1,727.40$ & $5,461.14$ & 39.17 & 148.67 \\
\hline
\end{tabular}

Table 1. Overall contribution of Nepal Telecom to the Government of Nepal from F/Y 2007/08 to 2016/17.

Source: Annual report of Nepal Telecom, F/Y 2007/08 to 2016/17

Table 1 shows that advance income tax payment to government although is increasing, however, it has been fluctuating over past 10 years. On an average, it has contributed Rs. 4,790.5 million with a weight of around twenty-six percent to the government revenue. Similarly, VAT and telecommunication fees are increasing and are contributing around seventeen and eleven percent to the revenue. Ownership fees, custom duty and royalty and rural telecommunication development funds have also shown fluctuating trends in their contribution to the government. From the table, dividend has overall increasing trend with a weight of around thirty percent contribution to the government. Property and vehicle tax although has doubled over the past ten years however it is fluctuating and contributing less than one percent to government revenue.

\subsection{Total Tax Contribution from Nepal Telecom}

From the overall contributions, total tax contributions by Nepal Telecom to the government of Nepal in different years are mainly, property and vehicle tax, income tax, VAT, TDS, and custom duty. 
Table 2. Total tax contribution from Nepal Telecom.

\begin{tabular}{lllllll}
\hline & & & & & & (Rs in million) \\
\hline F/Y & Property and vehicle tax & Income tax & VAT & Tax deduction at source & Custom duty & Total taxes \\
\hline $2007 / 08$ & 28.08 & $3,130.32$ & $1,441.03$ & $2,838.26$ & 246.09 & $7,683.78$ \\
$2008 / 09$ & 33.59 & $3,642.59$ & $1,768.33$ & $3,648.71$ & 214.89 & $9,308.11$ \\
$2009 / 10$ & 27.62 & $4,467.92$ & $2,736.60$ & $4,231.40$ & 260.48 & $11,724.02$ \\
$2010 / 11$ & 45.27 & $4,927.43$ & $2,127.50$ & $4,477.41$ & 228.96 & $11,806.58$ \\
$2011 / 12$ & 44.95 & $4,634.54$ & $2,452.62$ & $5,270.10$ & 122.22 & $12,524.43$ \\
$2012 / 13$ & 42.33 & $4,310.97$ & $3,560.09$ & $3,630.93$ & 527.92 & $12,072.25$ \\
$2013 / 14$ & 42.45 & $4,402.58$ & $3,865.70$ & $7,075.94$ & 190.22 & $15,576.89$ \\
$2014 / 15$ & 47.47 & $6,101.39$ & $4,152.24$ & $4,849.35$ & 123.48 & $15,273.93$ \\
$2015 / 16$ & 45.17 & $4,564.29$ & $4,352.16$ & $5,734.59$ & 308.37 & $15,004.57$ \\
$2016 / 17$ & 34.80 & $5,734.01$ & $4,752.77$ & $6,148.28$ & 368.32 & $17,038.19$ \\
Total & 391.72 & $45,916.04$ & $31,209.03$ & $47,904.98$ & $2,590.96$ & $128,012.74$ \\
Average & 39.17 & $4,591.60$ & $3,120.90$ & $4,790.50$ & 259.10 & $12,801.27$ \\
\hline
\end{tabular}

Source: Annual Report of Nepal Telecom, F/Y 2007/08 to 2016/17

Table 2 shows the total tax contributions of Nepal Telecom to the government of Nepal, which includes both direct and indirect taxes. Among them, property and vehicle tax, income tax and tax deduction at source comprises of direct tax, whereas, VAT and custom duty comprises of indirect tax. It has been observed that, both property and vehicle taxes have been increasing from $\mathrm{F} / \mathrm{Y} 2007 / 08$ at 28.08 million to 34.8 million with highest on $\mathrm{F} / \mathrm{Y} 2014 / 15$ at 47.47 million. It has decreased on F/Y 2009/10, 2011/12, 2012/13, 2015/16. On an average it has contributed 39.17 million over time. Income tax payable has shown increasing trend from F/Y 2007/08 at 3,130.32 million to $F / Y 2016 / 17$ at 5,734.01 million which has increased by around two times over time. On an average it has contributed 4,591.6 million over time. VAT has shown increasing trend from F/Y 2007/08 at 1,441.03 million to $F / Y$ 2016/17 at 4,752.77 million which has increased by around three times over time. On an average it has contributed 3,120.9 million over time. Tax deduction at source has shown increasing trend from F/Y 2007/08 at 2,838.26 million to F/Y $2016 / 17$ at $6,148.28$ million which has increased by around two times over time. On an average it has contributed 4,790.5 million over time. Custom duty has shown increasing as well as decreasing trend from $\mathrm{F} / \mathrm{Y} 2007 / 08$ at 246.09 million to F/Y 2016/17 at 368.32 million which has increased by around one point four nine times over time. On an average it has contributed 259.1 million over time.

\subsection{Co-relation Analysis}

Co-relation coefficient between government revenue and total tax contribution of Nepal Telecom has been calculated according to Table 3 .

Table 3. Co-relation between government revenue and total tax contributions of Nepal Telecom to the government of Nepal.

\begin{tabular}{lll}
\hline & & (Rs in million) \\
\hline F/Y & Government Revenue & Tax Contribution \\
\hline $2007 / 08$ & $107,622.50$ & $7,683.78$ \\
$2008 / 09$ & $143,474.50$ & $9,308.11$ \\
$2010 / 11$ & $177,991.70$ & $11,724.02$ \\
$2011 / 12$ & $198,375.90$ & $11,806.58$ \\
$2012 / 13$ & $244,374.00$ & $12,524.43$ \\
$2013 / 14$ & $296,021.10$ & $12,072.25$ \\
$2014 / 15$ & $356,620.70$ & $15,576.89$ \\
$2015 / 16$ & $405,866.40$ & $15,273.93$ \\
$2016 / 17$ & $481,961.60$ & $15,004.57$ \\
\hline
\end{tabular}

Source: Economic Survey, Ministry of Finance, Government of Nepal, F/Y 2007/08 to 2016/17; Annual report of Nepal Telecom, F/Y 2007/08 to 2016/17

\begin{tabular}{llll}
\hline Correlations & & Government Revenue & Tax Contribution \\
\hline \multirow{3}{*}{ Government Revenue } & Pearson Correlation & 1 & $.919^{* *}$ \\
& Sig. (2-tailed) & & .000 \\
& $\mathrm{~N}$ & 10 & 10 \\
Tax Contribution & Pearson Correlation & $.919^{* *}$ & 1 \\
& Sig. (2-tailed) & .000 & 10 \\
\hline
\end{tabular}

**. Correlation is significant at the 0.01 level (2-tailed).

The data of government revenue has been ta Let government revenue and tax contribution be represented by variable $(\mathrm{X})$ and $(\mathrm{Y})$ respectively. Then co-relation between
$(\mathrm{X})$ and $(\mathrm{Y})$ is $(\mathrm{r})=0.919$. This means correlation is strong and the variables are positively co-related. Thus, the correlation is significant at 0.01 level of significance. 


\subsection{Multiple Regression Analysis}

Multiple regression of government revenue with income tax, VAT and TDS contributed to government from Nepal Telecom has been calculated according to Table 4 .

Table 4. Multiple regression of government revenue with income tax, VAT and TDS from Nepal Telecom.

\begin{tabular}{|c|c|c|c|c|}
\hline & & & & (Rs in million) \\
\hline $\mathbf{F} / \mathbf{Y}$ & Government revenue & Income tax & VAT & TDS \\
\hline $2007 / 08$ & $107,622.50$ & $3,130.32$ & $1,441.03$ & $2,838.26$ \\
\hline $2008 / 09$ & $143,474.50$ & $3,642.59$ & $1,768.33$ & $3,648.71$ \\
\hline $2009 / 10$ & $177,991.70$ & $4,467.92$ & $2,736.60$ & $4,231.40$ \\
\hline $2010 / 11$ & $198,375.90$ & $4,927.43$ & $2,127.50$ & $4,477.41$ \\
\hline $2011 / 12$ & $244,374.00$ & $4,634.54$ & $2,452.62$ & $5,270.10$ \\
\hline $2012 / 13$ & $296,021.10$ & $4,310.97$ & $3,560.09$ & $3,630.93$ \\
\hline $2014 / 15$ & $405,866.40$ & $6,101.39$ & $4,152.24$ & $4,849.35$ \\
\hline $2015 / 16$ & $481,961.60$ & $4,564.29$ & $4,352.16$ & $5,734.59$ \\
\hline $2016 / 17$ & $609,180.00$ & $5,734.01$ & $4,752.77$ & $6,148.28$ \\
\hline
\end{tabular}

Source: Economic Survey, Ministry of Finance, Government of Nepal, F/Y 2007/08 to 2016/17; Annual report of Nepal Telecom, F/Y 2007/08 to 2016/17

We have equation of multiple regression,

$$
\mathrm{Y}=\mathrm{a}+\mathrm{b}_{1} \mathrm{X}_{1}+\mathrm{b}_{2} \mathrm{X}_{2}+\mathrm{b}_{3} \mathrm{X}_{3}
$$

Where, $\mathrm{Y}=$ Government revenue, $\mathrm{a}=\mathrm{Y}$ intercept, $\mathrm{b}=$ Slope

Variables Entered/Removed ${ }^{\mathrm{a}}$

$$
\begin{array}{ll}
\text { Model } & \text { Variables Entered } \\
1 & \text { TDS, Income Tax, VAT }
\end{array}
$$

coefficient, $\mathrm{X}_{1}=$ Income tax from Nepal Telecom, $\mathrm{X}_{2}=\mathrm{VAT}$ from Nepal Telecom, $X_{3}=$ TDS from Nepal Telecom We have calculations from the statistical software SPSS as:

\begin{tabular}{|c|c|c|c|c|}
\hline Model & $\mathrm{R}$ & R Square & Adjusted R Square & Std. Error of the Estimate \\
\hline 1 & $.952^{\mathrm{a}}$ & $.905^{1}$ & .858 & 60604.6204 \\
\hline
\end{tabular}

a. Dependent Variable: Government Revenue

b. All requested variables entered.

a. Predictors: (Constant), TDS, Income Tax, VAT

Variables Removed

Method

Enter

$\begin{array}{lllllll}\text { ANOVA }^{\mathrm{a}} & & & & & \\ \text { Model } & & \text { Sum of Squares } & \text { df } & \text { Mean Square } & \text { F } & \text { Sig. } \\ & \text { Regression } & 210865100501.943 & 3 & 70288366833.981 & 19.137 & .002^{\mathrm{b}} \\ 1 & \text { Residual } & 22037520104.021 & 6 & 3672920017.337 & & \\ & \text { Total } & 232902620605.964 & 9 & & \end{array}$

a. Dependent Variable: Government Revenue

b. Predictors: (Constant), TDS, Income Tax, VAT

Coefficients $^{\mathrm{a}}$

Model

1

\begin{tabular}{lll} 
& \multicolumn{2}{l}{ Unstandardized Coefficients } \\
& B & Std. Error \\
(Constant) & -176234.873 & 121703.595 \\
Income Tax & 14.151 & 33.113 \\
VAT & 113.292 & 29.887 \\
TDS & 12.491 & 22.269
\end{tabular}

Standardized Coefficients Beta

.100

\author{
60604.6204
}

a. Dependent Variable: Government Revenue

According to calculations, the correlation value of $\mathrm{R}$ is 0.952. It means the combined correlation between income tax, VAT and TDS tax with government revenue is 0.952 which implies that the independent variables are strongly positively correlated with government revenue. Coefficient of determination $\mathrm{R}$ square is a statistical measure of closeness of data fitted in regression line. $\mathrm{R}$ square obtained is 0.905 and adjusted $\mathrm{R}$ square obtained is 0.858 It implies the model explains 90.5 percent variability around its mean. In general, the higher the R-squared, the better the model fits the data.

Putting the values of constant and coefficients in the regression equation (3), We have

$$
\mathrm{Y}=-176234.87+14.151 \mathrm{X}_{1}+113.292 \mathrm{X}_{2}+12.491 \mathrm{X}_{3}
$$


From the analysis of data of past ten years, the $\mathrm{Y}$ intercept ' $a$ ' is 176234.87 which indicates that the value of government revenue becomes 176,234.87 million rupees when the independent variables, income tax, VAT and TDS are zero. When income tax from Nepal Telecom increases by one time, government revenue increases by 14.51 times. Similarly, when VAT from Nepal Telecom increases by one time, government revenue increases by 113.292 times. Similarly, when TDS from Nepal Telecom increases by one time, government revenue increases by 12.491 times.

The t- value of income tax, VAT and TDS are 0.427, 3.791 and 0.561 respectively. The p-value of income tax, VAT and TDS are $0.684,0.009$ and 0.595 .

This shows that only VAT has significant relationship with dependent variable, government revenue as its p-value is less than 0.05 at 5 percent level of significance which implies that null hypothesis is rejected and alternative hypothesis is accepted.

Whereas, income tax and TDS have p-values greater than 0.05 at 5 percent level of significance thus these independent variables do not have significant relationship with the dependent variable, government revenue which implies that null hypothesis is not rejected.

The calculated F-value is 19.137 at 0.002 significance which shows the calculated $F$ is greater than tabulated F. It shows that null hypothesis is rejected and alternative hypothesis is accepted at 5 percent level of significance.

\subsection{Time Series Analysis}

Time series analysis of total tax contribution to government from Nepal Telecom has been calculated according to Table 5 .

Table 5. Time series analysis of total tax contribution to government from Nepal Telecom

\begin{tabular}{ll}
\hline & (Rs in million) \\
\hline F/Y & Tax contribution \\
\hline $2007 / 08$ & $7,683.78$ \\
$2008 / 09$ & $9,308.11$ \\
$2009 / 10$ & $11,724.02$ \\
$2010 / 11$ & $11,806.58$ \\
$2011 / 12$ & $12,524.43$ \\
$2012 / 13$ & $12,072.25$ \\
$2013 / 14$ & $15,576.89$ \\
$2014 / 15$ & $15,273.93$ \\
$2015 / 16$ & $15,004.57$ \\
$2016 / 17$ & $17,038.19$ \\
\hline
\end{tabular}

Source: Annual report of Nepal Telecom, F/Y 2007/08 to 2016/17

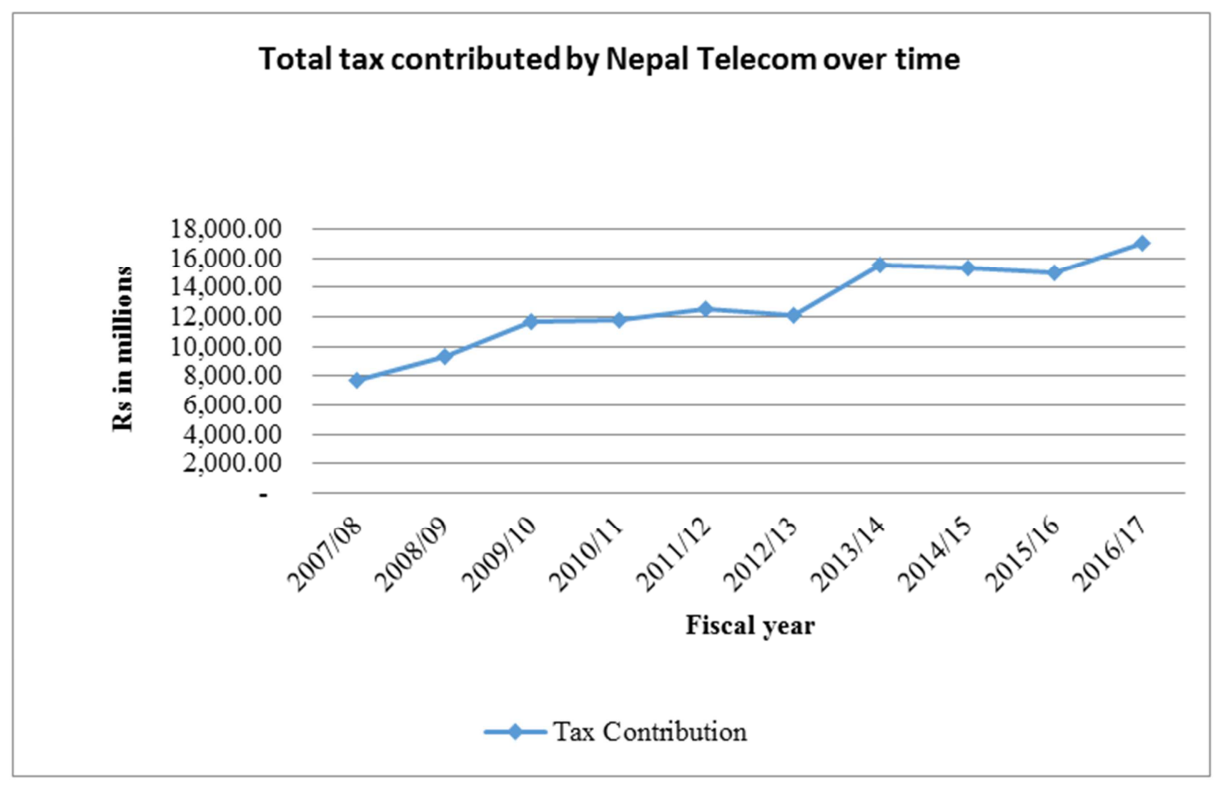

Figure 1. Time series analysis of total tax contributed by Nepal Telecom to GON.

Table 6. Calculation for least square method.

\begin{tabular}{|c|c|c|c|c|}
\hline Fiscal year & Deviation taken from the year of origin $(\mathrm{X})$ & Tax revenue(Y) & $\mathrm{X}^{2}$ & XY \\
\hline $2007 / 08$ & -4.5 & $7,683.78$ & 20.25 & $(34,577.03)$ \\
\hline $2008 / 09$ & -3.5 & $9,308.11$ & 12.25 & $(32,578.38)$ \\
\hline $2009 / 10$ & -2.5 & $11,724.02$ & 6.25 & $(29,310.04)$ \\
\hline $2011 / 12$ & -0.5 & $12,524.43$ & 0.25 & $(6,262.21)$ \\
\hline $2012 / 13$ & 0.5 & $12,072.25$ & 0.25 & $6,036.13$ \\
\hline $2013 / 14$ & 1.5 & $15,576.89$ & 2.25 & $23,365.34$ \\
\hline $2015 / 16$ & 3.5 & $15,004.57$ & 12.25 & $52,515.99$ \\
\hline $2016 / 17$ & 4.5 & $17,038.19$ & 20.25 & $76,671.86$ \\
\hline Total & $\sum X=0$ & $\sum Y=128,012.74$ & $\sum X^{2}=82.5$ & $\sum X Y=76,336.62$ \\
\hline
\end{tabular}


The equation of straight line trend is,

$$
Y=\mathrm{a}+\mathrm{b} X
$$

where,

$Y=$ Dependent variable i.e. Tax contribution

$X=$ Independent variable i.e. Time

Using Least Square Method the value of variable 'a' and variable ' $b$ ' can be obtained through

$$
\begin{aligned}
& \sum Y=N a+\sum X \\
& \sum X Y=a \sum X+b \sum X^{2}
\end{aligned}
$$

Let year of origin is $\mathrm{F} / \mathrm{Y} 2012$

From equation (5) and according to Table $6 \sum Y=N a+\sum X$ $\mathrm{a}=\frac{\sum Y}{N}$ as $X$ is $0, \mathrm{a}=\frac{128012.74}{10}=12,801.27$, From equation (10), $\sum X Y=a \sum X+b \sum X^{2}, \sum X Y=b \sum X^{2}($ as $X=0), \mathrm{b}=\frac{\sum X Y}{\sum X^{2}}$, $\mathrm{b}=\frac{76336.62}{82.5}=925.29$. The equation of straight line trend is for $\mathrm{F} / \mathrm{Y} 2021 / 22,5$ years from $\mathrm{F} / \mathrm{Y} 2016 / 17$ where $X=9.5$ is $Y$ $=\mathrm{a}+\mathrm{b} X, Y=12801.27+925.29 \times 9.5=21,591.55$

Total tax contribution from Nepal Telecom is taken as dependent variable $(Y)$ and time from fiscal year 2007/08 to $2016 / 17$ is taken as independent variable $(X)$.

The calculated value of $a=12801.27$ and $b=925.29$. Then, putting the value of ' $a$ ' and ' $b$ ' in the above equation (4). We have,

$$
\mathrm{Y}=12801.27+925.29 \mathrm{X}
$$

We tend to find time series analysis for five years later. So, the variable ' $\mathrm{X}$ ' denoting time be $\mathrm{X}=9.5$, then the above equation (4) becomes,

$$
\mathrm{Y}=12801.27+925.29 \times 9.5=21,591.55
$$

Thus, the time series shows that total tax contribution to government from Nepal Telecom shall be Rs 21,591.55 million in F/Y 2021/22 five years later if the trend of past ten years continues in this way.

\subsection{Recognition of Areas for Improving the Tax Payment System of Nepal Telecom While Furnishing Tax Returns to Inland Revenue Department (IRD)}

Tax being a matter which requires timely assessment and also the procedural aspects have to be followed with utmost care, Nepal Telecom which has a comparatively huge tax contribution, there will certainly be areas for improvement in the tax payment system. This led to analyze the areas for recognition and improvement perspective as a part of the research. The areas recognized in course of tax payment system of Nepal Telecom has been collected through checklist (Appendix 2) were as follows:

i. Regarding the expenses where deductions are not allowed by tax officers, expenses without proper supporting documents, are recognized as the major problems by the key informants and are added back before tax calculation. Some recognized expenses that are not genuine also as unallowable ones.

ii. Duty of timely recording of the transactions without delay is recognized as major difficulty, by majority of the key informants. In case of difficulty, faced in determination of income, expenses deduction, tax determination and tax payment. Some recognized lack of proper information from accounting software also as a difficulty, while some recognized full time involvement of staffs in account division as a difficulty.

iii. Annexure thirteen of IRD which contains balance of sales transactions, purchase transactions, debtors and creditors is recognized as the annexure which is most questioned by IRD officials and made liable to pay fines and penalties at the time of full audit, as responded by all of the informants.

iv. In regard of the practical problem faced by accounts department for tax determination in central office, incompetent staffs at branches and divisions is recognized as major practical problem by majority of key informants. Some also recognized untimely recording of transactions by staffs from all over the country's branches and divisions as the practical problem.

v. Complexity in tax assessment, is recognized as possible problem in Nepal Telecom regarding income tax as per majority of informants. Some recognized huge volume of tax assessment also as possible problem.

The improvement areas recognized in the existing scenario of tax furnishing and payment system of Nepal Telecom are as follows:

i. System of tax refund in some sectors is recognized by majority of key informants, which may keep Nepal Telecom as one of the highest tax paying organization in future as well. Some informants also recognized subsidy in remote areas as an encouraging step from government side.

ii. Improvements in tax system; procedure of tax assessment, furnishing of return to IRD and payment on income tax is recognized as the prime area for improving the tax system of Nepal Telecom by majority of the informants. Some informants also recognized proper disclosure of contribution of direct and indirect tax and fees to government as area for improvement pointed by statutory auditor and Office of Auditor General.

iii. Regarding reduction of problems in tax payment system of Nepal Telecom, majority of the informants recognized open and transparent atmosphere among the stakeholders of Nepal Telecom. While, some informants recognized strict compliance requirement as a step for reduction of problem. 


\section{Conclusions}

Over the past ten years, Nepal Telecom has been contributing significant portion of tax revenue through income tax, value added tax, tax deduction at source, property and vehicle tax and custom duty. It has also been contributing to government of Nepal through various regulatory fees. The statistical analysis demonstrated that government revenue is highly related and dependent on with the income tax, VAT and TDS contributed from Nepal Telecom. Thus, Nepal Telecom has been identified as major contributor of tax to the government of Nepal. Complexity regarding tax assessment, improper documentation of expenses, untimely recording of transactions, mismatched balances in annexure thirteen of IRD, improper support from branches have been recognized as existing problem in the areas of tax payment system of Nepal Telecom.

\section{Recommendations}

Nepal telecom has been one of the leading tax paying pubic companies in Nepal, but, it has areas for improvements in the tax payment system. Major recommendations provided by the key informants of Central office in Nepal Telecom has been mentioned hereafter. First of all, tax assessment according to the provisions of Nepal Financial Reporting Standards (NFRS) can reduce complexity in income tax assessment to large extent. Secondly, internal audit and adherence of compliance procedures, can solve the problem of improper documentation of expenses and irregular recording of transactions. Thirdly, party ledger and party statements must be reviewed as soon as termination of fiscal year such that, mismatch of balances with parties in annexure thirteen of IRD can be prevented, while furnishing of tax returns. These three recommendations provided by key informants shall certainly help to execute on the existing problems.

Being a researcher, even I realized some of the areas for improvements. At first, tax refund in some sectors and open environment from stakeholders can also be possible suggestions. Secondly, globally telecommunication charges are decreasing but in Nepal it is still expensive. Nepal Telecom must reduce its charges on calls, internet, data and other sectors. This can be done by reduction of rate of VAT on PSTN phone and mobile phones. Thirdly, the government must also take steps for reduction of VAT rate at basic phone and mobile calls. At last I assume, Nepal Telecom should have a practice of utilizing the goods and services developed in Nepal itself such that resource and technology developed in Nepal is used to enhance telecommunication sector of the country. It might also promote for research and production of telecommunication equipment and technologies through various funding packages at colleges and universities or other research institutes.

\section{Acknowledgements}

First of all, I would like to thank Tribhuvan University for giving me the chance to prepare the thesis for a partial fulfillment of the requirement for the Master's Degree of Business Studies program held under Tribhuvan University. After the long period of continuous survey and sincere efforts, this research has been conducted. On this occasion, I would like thank my thesis supervisor Dr. Jitendra Prasad Upadhyay and all supportive people who directly or indirectly guided me to draft a dissertation in this issue. My special thanks goes to the staffs of Nepal Telecom Company Limited, Bhadrakali for providing me necessary materials and helping me in each possible ways. In this regard, I also would like to remember all my colleagues, friends, the lectures and administrative staffs of Nepal Commerce Campus, my family members for their continuous support and helping me in this research work.

\section{Abbreviations}

$\begin{array}{ll}\text { A. D. } & \text { Anno Domini } \\ \text { ADSL } & \text { Asymmetric Digital Subscriber Line } \\ \text { CDMA } & \text { Code Division Multiple Access } \\ \text { e.g. } & \text { Example } \\ \text { etc. } & \text { Etcetera } \\ \text { E/Y } & \text { Ernst \& Young } \\ \text { F/Y } & \text { Fiscal Year } \\ \text { FMCG } & \text { Fast-Moving Consumer Goods } \\ \text { FTTH } & \text { Fiber to the Home } \\ \text { GON } & \text { Government of Nepal } \\ \text { GSM } & \text { Global System for Mobile communications } \\ \text { IRD } & \text { Inland Revenue Department } \\ \text { MD } & \text { Managing Director } \\ \text { MOF } & \text { Ministry of Finance } \\ \text { MMS } & \text { Multimedia Messaging Service } \\ \text { NFRS } & \text { Nepal Financial Reporting Standards } \\ \text { NT } & \text { Nepal Telecom } \\ \text { NTC } & \text { Nepal Telecom Corporation } \\ \text { OECD } & \text { Organization for Economic Co-operation and } \\ \text { SMS } & \text { Development } \\ \text { S.N. } & \text { Short Message Service } \\ \text { SPSS } & \text { Serial Number } \\ \text { TDS } & \text { Statistical Package for Social Sciences } \\ \text { T.U. } & \text { Tax Deduction at Source } \\ \text { VAT } & \text { Tribhuvan University } \\ & \text { Value Added Tax } \\ & \end{array}$

\section{Appendix}

Questionnaire prepared in order to recognize problems for improving existing scenario of income tax payment system of Nepal Telecom

1. What are expenses where deductions are not allowed by Tax Officers in most of the cases?
a) Personal nature expenses
b) Expenses without proper supporting documents
c) Expenses that are not genuine
d) Over stated expenses

2. Among the difficulties faced in determination of 
income, expenses deduction, tax determination and tax payment, which is the major one?

a) Duty of timely recording of the transactions without delay

b) Full time involvement of staffs in account division

c) Lack of proper information from accounting software

d) Improper information on time due to lack of coordination among staffs

3. Among the details to be furnished to Inland Revenue Department (IRD), which annexure is often raised then questioned by IRD and has made to pay maximum fines and penalties in full audit?

a) Annexure 2 (Tax calculation details)

b) Annexure 5 (Business income details)

c) Annexure 10 (Advance income tax balance details)

d) Annexure 13 (Sales, purchase, debtors and creditors details)

4. What is the major practical problem faced by Accounts Department for Tax Determination in Central Office?

a) Untimely recording of transactions like sales and purchase by staffs from all over the country branches and divisions

b) Lack of timely information for sales returns, purchase returns, omission of items or various issued from the parties on time.

c) Incompetent staffs in branches and divisions

d) Pressure from employee union and top management

5. What are the possible problems in Nepal Telecom regarding Income Tax?
a) Huge volume of Tax Assessment
b) Complexity in Tax Assessment
c) Procedural requirements in Tax Payment
d) Filing of Tax Returns with Inland Revenue Department

6. Nepal Telecom is one of the highest tax paying organization in the country. What might be one encouraging step by the government which might encourage Nepal Telecom to be among highest tax paying organization also future?

a) Exemption in some specific sectors for tax payment

b) Subsidy in remote areas

c) Concession in the basic tax rate

d) System of tax payment refund in some of the sectors

7. What is the prime area where the statutory auditor and Office of Auditor General has pointed for improvements in tax system?

a) Inadmissible expenses which are added back and tax is paid on added back amount

b) Proper disclosure of contribution of direct and indirect tax and fees to government

c) Procedure of income tax assessment, furnishing of return to IRD and payment on income tax

d) Others if any

8. How can problems in income tax payment system of Nepal Telecom be reduced?

a) Knowledge and efficiency among the accounts department staffs b) Knowledge and efficiency among the various parties transacting with Nepal Telecom

c) Strict compliance requirements

d) Open and transparent atmosphere among the stakeholders of Nepal Telecom

\section{References}

[1] J. Agrawal, "Income Tax: Theory and Practice", Ayam Publication, 2009.

[2] J. B. K. C., "Tax Laws and Tax Planning", Khanal Books \& Stationery, 2006.

[3] K. D. Dhakal, I. P. Bhattarai, G. P. Koirala and R. Bhattarai, "Tax Laws \& Tax Planning in Nepal", Asmita Books \& Distributors, 2017.

[4] Nepal Telecom, “www.ntc.net.np”, 2018.

[5] L. H. Roller, L. Waverman, "Telecommunications Infrastructure and Economic Development: A Simultaneous Approach", Social Science Research Center, Berlin, July 1996.

[6] Nepal Rastra Bank, "Trend in Nepal's import duties: Implications with future trade liberalization", Economic Review, 2002, pp. 152-174.

[7] Telecommunication Development Bureau, "Taxing telecommunication/ ICT services: an overview", International Telecommunication Union, Geneva, June 2013.

[8] Nepali Telecom, “www.nepalitelecom.com”, Nov. 2016.

[9] J. Luan, "A Comparative Study on Replacing Business Tax with Value-Added Tax of Domestic and Foreign Telecommunication Industry", International Conference on Judicial, Administrative and Humanitarian Problems of State Structures and Economical Subjects, 2016, Yantai, China, pp. 0129-0132.

[10] M. U. Din, I. U. Mangla, M. Jamil, "Public Policy, Innovation and Economic Growth: An Economic and Technological Perspective on Pakistan's Telecom Industry", The Lahore Journal of Economics, Sept. 2016, pp. 369-391.

[11] EY, "US tax reform and the telecommunications industry", www.ey.com/telecommunications, 2017.

[12] T. Matheson and P. Petit, "Taxing Telecommunications in Developing Countries", IMF Working Paper, Nov. 2017, pp. 1-42.

[13] S. Forogh, S. Dasanayaka, O. A. Serhan, A. A. Alariki, R. Houjeir, I. Recezy, "Service Quality Factors Influencing Customer Satisfaction in Afghanistan's Mobile Telecommunication Industry", International Journal of Economics Perspectives, Vol. 11, 2017, pp. 119-133.

[14] T. Svetalekth, "Should Excise Tax be collected on Mobile Services? Experience in Thailand", International Conference on Technology, Innovation and Industrial Management, 16-18 May 2018, Naples, Italy, pp. 251-258.

[15] L. Mehta, B. Kaur, "Tax Payer's Perception towards Goods and Service Tax in India", International Conference on Management and Information Systems, 21-22 Sept. 2018, Chitkata University, pp. 81-87. 
[16] Economic Survey, F/Y 2016/17, Ministry of Finance, Government of Nepal, www.mof.gov.np, 2018.

[17] Annual Report of Nepal Telecom, F/Y 2016/17, "www.ntc.net.np", 2018.
[18] D. N. Gujrati, D. C Porter and S Gunasekar, "Basic Econometrics", McGraw Hill Education (India), 2015. 